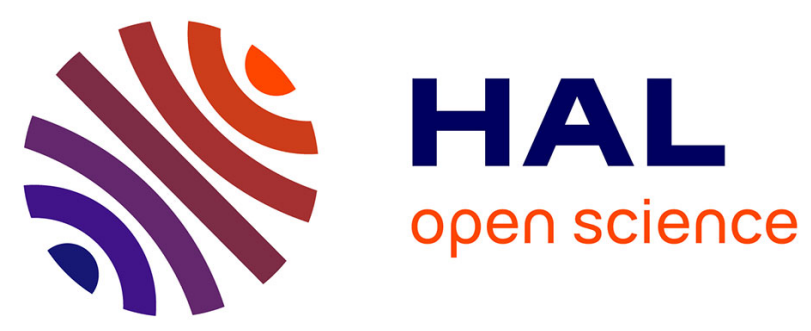

\title{
Isolation and structure elucidation of cyclopeptide alkaloids from the leaves of Heisteria parvifolia
}

Michel Boni Bitchi, Abdulmagid Alabdul-Magid, Faustin Aka Kabran, Philomène Akoua Yao-Kouassi, Dominique Harakat, Hamid Morjani, Félix Zanahi Tonzibo, Laurence Voutquenne-Nazabadioko

\section{To cite this version:}

Michel Boni Bitchi, Abdulmagid Alabdul-Magid, Faustin Aka Kabran, Philomène Akoua Yao-Kouassi, Dominique Harakat, et al.. Isolation and structure elucidation of cyclopeptide alkaloids from the leaves of Heisteria parvifolia. Phytochemistry, 2019, 167, pp.112081. 10.1016/j.phytochem.2019.112081. hal-02310316v1

\section{HAL Id: hal-02310316 https: / hal.univ-reims.fr/hal-02310316v1}

Submitted on 22 Sep 2021 (v1), last revised 24 Sep 2021 (v2)

HAL is a multi-disciplinary open access archive for the deposit and dissemination of scientific research documents, whether they are published or not. The documents may come from teaching and research institutions in France or abroad, or from public or private research centers.
L'archive ouverte pluridisciplinaire HAL, est destinée au dépôt et à la diffusion de documents scientifiques de niveau recherche, publiés ou non, émanant des établissements d'enseignement et de recherche français ou étrangers, des laboratoires publics ou privés. 
Isolation and structure elucidation of cyclopeptide alkaloids from the leaves of Heisteria parvifolia

Michel Boni Bitchi ${ }^{\mathrm{a}, \mathrm{b}}$, Abdulmagid Alabdul Magid ${ }^{\mathrm{b}, *}$, Faustin Aka Kabran ${ }^{\mathrm{a}}$, Philomène Akoua Yao-Kouassi $^{\mathrm{a}}$, Dominique Harakat ${ }^{\mathrm{c}}$, Hamid Morjani ${ }^{\mathrm{d}}$, Félix Zanahi Tonzibo ${ }^{\mathrm{a},{ }^{*}}$, Laurence Voutquenne-Nazabadioko ${ }^{\mathrm{b}}$

${ }^{a}$ Laboratoire de Chimie Organique Biologique, UFR Sciences des Structures de la Matière et Technologie, Université Félix Houphouët-Boigny, 22 BP 582 Abidjan 22, Cote d'Ivoire

bICMR-UMR CNRS 7312, Chimie des Substances Naturelles, Campus Sciences, Bât. 18, BP 1039, 51687 Reims, France

'Service Commun d'Analyses, Institut de Chimie Moléculaire de Reims (ICMR), CNRS

UMR 7312, Bat. 18 B.P. 1039, 51687 Reims Cedex 2, France

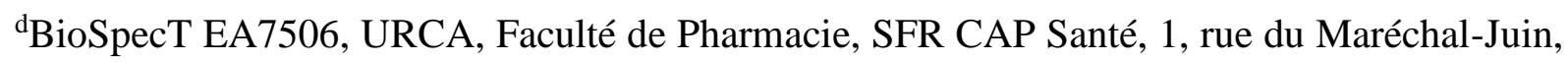
51096 Reims, France

*Corresponding authors. Tel: +22505071967

E-mail address: tonzibz@yahoo.fr (F.Z. Tonzibo), abdulmagid.alabdulmagid@univ-reims.fr (A. Alabdul Magid) 


\title{
Highlights
}

- Five undescribed cyclopeptide alkaloids were isolated from Heisteria parvifolia $\mathrm{Sm}$.

Their structures were elucidated by 1D-, 2D-NMR and HR-ESI-MS analyses.

Their cytotoxicity against the chronic myeloid leukemia K562 cells was evaluated.

\begin{abstract}
Five undescribed cyclopeptide alkaloids, cycloheisterins A-E, together with one known compound were isolated from the leaves of Heisteria parvifolia. Their structures were established by different spectroscopic methods including 1D- and 2D-NMR experiments as well as HR-ESI-MS analysis. Their cytotoxic activity against the chronic myeloid leukemia (K562) cell line was evaluated.
\end{abstract}




\section{Introduction}

Cyclopeptide alkaloids are widespread and occur in several families: Asteraceae, Celastraceae, Euphorbiaceae, Fabaceae, Menispermaceae, Olacaceae, Pandaceae, Rhamnaceae, Rubiaceae, Sterculiaceae, and Urticaceae (El-Seedi et al. 2007, Gournelis et al. 1997, Morel et al. 2009, Tan and Zhou, 2006). Previous studies have reported cyclopeptides alkaloids from Heisteria nitida (El-Seedi et al. 1999, El-Seedi et al. 2005). The cyclopeptide alkaloids sensu stricto were classified according to the number of amino acid constituents outside and the size of the macrocycle (inside) as 4(13); 5(13); 4(14) and 4(15) type of alkaloids (Joullie and Richard, 2004; Tan and Zhou, 2006). Several activities of cyclopeptides alkaloids have been reported, such as antimicrobial (Gournelis et al. 1997, Morel et al. 2005), insecticidal (Sugawara et al. 1996), sedative (Suh et al. 1997), and antiplasmodiale activity (Suksamrarn et al. 2005).

The genus Heisteria belonging to the Olacaceae family comprises about 65 species in tropical America and 3 in Africa; namely H. parvifolia, H. trillesiana, and H. zimmereri. Heisteria parvifolia $\mathrm{Sm}$. is an evergreen shrub or small tree up to $15(-20) \mathrm{m}$ tall; $40(-60) \mathrm{cm}$ in diameter (Malaisse et al. 2004). H. parvifolia occurs from Senegal and south-western Mali eastward to the Central African Republic and southward DR Congo and northern Angola; possibly also in Uganda and southern Soudan (Louppe et al. 2008). In Ivory Coast, is locally abundant on sandy soils. Its wood is used for construction and tool handles. In several areas, the fruits are eaten fresh; the small oil-rich seeds are eaten fresh, roasted or cooked. The twigs are used as chewsticks. Various Heisteria species are used by South-American Indians or in Africa in the treatment of rheumatism, abscesses, headache, throat infections, swellings, nose bleedings, pain in joints and muscles, diarrhea, hepatic infection (Kvist and Holm-Nielsen, 1987; Russo, 1992; Tan and Zhou, 2006). In traditional medicine in Ghana, ground roots of H. parvifolia are applied as enema against stomach-ache. In Congo, sap from the root bark is used as dropps into the nose against migraine and into the eye to treat painful, infected eyes. Stem bark is taken in 
Ghana, Ivory Coast and DR Congo as cough medicine. In Gabon, bark is applied to circumcision wounds. In Ghana and Ivory Coast, leaf decotions are taken or applied as a bath to invigorate rachitic children and to treat convulsions. They are also used as analgesic and rubbed onto painful breasts of young mothers, and in Sierra Leone to treat tooth-ache. In Congo, leaf decoctions are administrated against asthma, costal pain, stomach pain, and menstrual problems. Ground seeds are used to stupefy fish. In DR Congo, powdered bark is an ingredient in the preparation of arrow poison (Abbiw, 1990; Burkill, 1997; Malaisse et al. 2004). Chemical investigations of Heisteria species have mainly revealed the presence of triterpenes and proanthocyanidines in H. pallida (Dirsch et al. 1992, Dirsch et al. 1993), cyclopeptide alkaloid in H. nitida (El-Seedi et al. 1999, El-Seedi et al., 2005), scopolamine in H. olivae (Cairo-Valera et al. 1977), and acetylenic fatty acids in H. accuminata (Kraus et al. 1998). Up to date, only the composition of the seeds oil of $H$. parvifolia has been reported as mainly long-chain saturated fatty acids, oleic acid and other mono and di enoic fatty acids (Malaisse et al. 2004). As a part of a continuing study for the discovery of medicinal Ivory Coast species, five undescribed cyclopeptide alkaloids (1-5), together with one known compound (6), have been isolated and characterized from the leaves of $H$. parvifolia. Their cytotoxicity against the chronic myeloid leukemia K562 cells was evaluated.

\section{Results and discussion}

The crude alkaloid extract prepared with an acid-base method of air-dried and pulverized leaves of $H$. parvifolia was subjected to silica gel flash chromatography, eluted with increasingly polar mixtures of $\mathrm{CHCl}_{3} / \mathrm{MeOH}$. Further purification was performed using semi-preparative HPLC. As a result, five undescribed cyclopeptide alkaloids (1-5) were isolated and chemically characterized, together with one known cyclopeptide alkaloids, anorldianine (6) (El-Seedi et al. 
1999). Their structures (Fig. 1) were elucidated by 1D- and 2D-NMR experiments and comparison with literature data, and confirmed by HR-ESI-MS.

The UV spectra of compounds 1-5 showed absorptions at 222-224 and 274-282 nm, wavelengths commonly assigned to peptide bonds and aromatic residues (Dongo et al. 1989; Kang et al. 2015, Schwing et al. 2011), while their IR spectra displayed bands at 3395 and 1682 $\mathrm{cm}^{-1}$, which are typical of amide groups (Dongo et al. 1989, Schwing et al. 2011).

Compound 1 was obtained as a white powder. Analysis of $\mathbf{1}$ by high-resolution electrospray ionization mass spectrometry (HR-ESI-MS) identified a pseudo-molecular ion $[\mathrm{M}+\mathrm{H}]^{+}$at $m / z$ 457.2807, corresponding to the molecular formula $\mathrm{C}_{25} \mathrm{H}_{36} \mathrm{~N}_{4} \mathrm{O}_{4}$ (calcd for $\mathrm{C}_{25} \mathrm{H}_{37} \mathrm{~N}_{4} \mathrm{O}_{4}$, 457.2815), in combination with analysis of NMR data. The ${ }^{13} \mathrm{C}$ NMR (Table 1) and HSQC spectra of 1 showed 25 carbon resonances for four methyls ( $\delta_{\mathrm{C}} 13.9,16.7,17.5$, and 19.5), one $N$-methyl ( $\delta_{\mathrm{C}} 31.8$ ), three methylenes ( $\delta_{\mathrm{C}} 23.3,28.2$, and 46.7$)$, twelve methines (two of which were olefinic carbons at $\delta_{\mathrm{C}} 116.7$ and 124.9 and four were aromatic carbons $s p^{2}$ at $\delta_{\mathrm{C}} 120.9$, $121.9,131.0$, and 131.4), two quaternary aromatic carbons ( $\delta_{\mathrm{C}} 157.2$ and 131.6), and three carbonyl carbons $\left(\delta_{\mathrm{C}} 171.1,167.5\right.$, and 165.2$)$. The ${ }^{1}$ NMR spectrum (Table 1$)$ displayed signals for two olefinic protons at $\delta_{\mathrm{H}} 6.53$ and 6.65, a singlet $N$-methyl $\left(\delta_{\mathrm{H}} 2.68\right)$, four methyl doublets, four aromatic protons, and several methine and methylene protons. The NMR data of compound 1 (Table 1) showed great similarity with the NMR data previously reported for anorldianine (compound 6) possessing a 14-membered ring type comprising a $p$-oxigenated $Z$-styrylamine group (Dongo et al. 1989, El-Seedi et al. 1999, El-Seedi et al. 2005). The presence of the $p$ oxigenated Z-styrylamine group was indicated by two doublets at $\delta_{\mathrm{H}} 6.53$ and 6.65 (each $1 \mathrm{H}, J$ $=7.7 \mathrm{~Hz} ; \mathrm{H}-1$ and $\mathrm{H}-2$, respectively) corresponding to the Z-double bond and four aromatic protons appearing as doublets of doublets with $J$-values typical for an $o, m$-coupling pattern $(\mathrm{H}-$ $12,13,15$, and 16$)$. The protons $\mathrm{H}-13$ and $\mathrm{H}-15\left(\delta_{\mathrm{H}} 7.11, \mathrm{dd}, J=8.7,2.4 \mathrm{~Hz}\right)$ showed correlation 
with C-1 $\left(\delta_{\mathrm{C}} 116.7\right)$ and $\mathrm{H}-12$ and $\mathrm{H}-16\left(\delta_{\mathrm{H}} 7.27, \mathrm{dd}, J=8.7,2.4 \mathrm{~Hz}\right)$ with $\mathrm{C}-14\left(\delta_{\mathrm{C}} 131.6\right)$ in HMBC spectrum. In cyclopeptide alkaloids, the $\mathrm{H}-9$ ( $\beta$-H of the $\beta$-hydroxy-amino acid moiety) chemical shift value (between 5.00 and $5.50 \mathrm{ppm}$ ) is characteristic. In this case, a doublets of doublets was present at $\delta_{\mathrm{H}} 4.92(J=8.3,1.5 \mathrm{~Hz})$. In the COSY spectrum, two cross peaks were observed for $\mathrm{H}-9\left(\delta_{\mathrm{H}} 4.92\right)$, more specifically with $\mathrm{H}-8\left(\delta_{\mathrm{H}} 5.01, \mathrm{~d}, J=8.3 \mathrm{~Hz}\right)$ and $\mathrm{H}-20\left(\delta_{\mathrm{H}}\right.$ 2.13, sept, $J=6.9 \mathrm{~Hz}$ ). The proton signal of the $\mathrm{CH}$-group in position 20 also showed cross peaks to $\mathrm{H}_{3}-21\left(\delta_{\mathrm{H}} 1.32, \mathrm{~d}, J=6.7 \mathrm{~Hz}\right)$ and $\mathrm{H}_{3}-22\left(\delta_{\mathrm{H}} 1.05, \mathrm{~d}, J=6.7 \mathrm{~Hz}\right)$. In the HMBC spectrum, correlations between $\mathrm{C}-9\left(\delta_{\mathrm{C}} 83.4\right)$ and H-21 and H-22 were observed (Fig. 2). These data agreed with previously reported data for $\beta$-hydroxyleucine (anorldianine). The methine and the methylene protons of proline were observed in the ${ }^{1} \mathrm{H}$ NMR spectrum: $\mathrm{H}-5\left(\delta_{\mathrm{H}} 4.16\right.$, $\mathrm{dd}, J=7.5,1.9 \mathrm{~Hz}), \mathrm{H}_{2}-17\left(\delta_{\mathrm{H}} 1.65, \mathrm{~m} ; 2.21, \mathrm{dd}, J=11.5-4.5 \mathrm{~Hz}\right), \mathrm{H}_{2}-18\left(\delta_{\mathrm{H}} 1.75, \mathrm{~m} ; 1.95, \mathrm{~m}\right)$, and $\mathrm{H}_{2}-19\left(\delta_{\mathrm{H}} 3.55\right.$, brt, $\left.J=9.8 \mathrm{~Hz} ; 3.85, \mathrm{~m}\right)$. In the COSY spectrum, cross peaks were observed between $\mathrm{H}-5 / \mathrm{H}-17, \mathrm{H}-17 / \mathrm{H}-18$, and $\mathrm{H}-18 / \mathrm{H}-19$. In the HMBC spectrum, the H-5 exhibited correlations with C-19 $\left(\delta_{\mathrm{C}} 46.7\right)$ and with the carbonyl C-4 $\left(\delta_{\mathrm{C}} 167.5\right)$ (Fig. 2). The methyl doublets of $N$-methyl-valine $\left(\mathrm{H}-2^{\prime}\right.$ and $\left.\mathrm{H}^{-} 3^{\prime}\right)$ appeared at $\delta_{\mathrm{H}} 0.95(\mathrm{~J}=6.7 \mathrm{~Hz})$ and $0.96(J=6.7$ $\mathrm{Hz})$ and the methine proton $\left(\mathrm{H}-1^{\prime}\right)$ of this moiety appeared as septuplet at $\delta_{\mathrm{H}} 2.13(\mathrm{~J}=6.9 \mathrm{~Hz})$. The HMBC experiment showed correlations between C-24 $(\delta 165.2)$ and H-25 $\left(\delta_{\mathrm{H}} 3.57, \mathrm{~d}, J=\right.$ $5.4 \mathrm{~Hz})$ and $\mathrm{H}-1$ ', and between the $N$-methyl carbon $\left(\delta_{\mathrm{C}} 31.8\right)$ and the $\mathrm{H}-25$ for this moiety. The combined use of 1D $\left({ }^{1} \mathrm{H}\right.$ and ${ }^{13} \mathrm{C}$ NMR) and 2D (COSY, HSQC, and HMBC) spectra allowed an unambiguous assignment of all protons and carbons of the amino acids units $(\beta$ hydroxyleucine, proline, $N$-methyl-valine residues) and the $p$-oxygenated $Z$-styrylamine group (Table 1). Moreover, the connectivity between the constitutive parts of the molecule were ascertained by the HMBC correlations between the carbonyl C-4/H-2, the carbonyl C-7/H-5, the carbonyl C-24/H-8, and C-11/H-9 (Fig. 2). Moreover, the NOE relationships H-8/H-25, H8/ H-12 and H-9/H-16 agreed with the $\beta$-hydroxyleucine connection with the $N$-methyl-valine 
and the $p$-oxygenated $Z$-styrylamine moieties whereas the NOE effects between $\mathrm{H}-8 / \mathrm{H}-19$ agreed with the connection of $\beta$-hydroxyleucine with proline (Fig. 2). Compound 1 was named cycloheisterin A after its plant origin (Fig. 1).

Compound 2 displayed an $[\mathrm{M}+\mathrm{H}]^{+}$ion peak at $m / z$ 471.2979 in the positive HR-ESI-MS, corresponding to the molecular formula $\mathrm{C}_{26} \mathrm{H}_{38} \mathrm{~N}_{4} \mathrm{O}_{4}$, suggesting an additional methyl group compared to $\mathbf{1}$. The NMR spectroscopic data of $\mathbf{2}$ were almost identical with those of $\mathbf{1}$ except for one additional methyl group (Table 1). The detailed analysis of the 2D-NMR spectra led to the identification, as in $\mathbf{1}$, of the amino acids units $(\beta$-hydroxyleucine, proline, and valine residues) and the $p$-oxygenated $Z$-styrylamine group (Table 1). The HMBC cross-peaks of the methyl signals at $\delta_{\mathrm{H}} 2.92(6 \mathrm{H}, \mathrm{s})$ to $\mathrm{C}-25\left(\delta_{\mathrm{C}} 72.7\right)$ of the valine residue indicated that the terminal amino acid in $\mathbf{2}$ is $N, N$-dimethyl-valine. Compound $\mathbf{2}$ was named cycloheisterin B. Compound 3 displayed an $[\mathrm{M}+\mathrm{Na}]^{+}$ion peak at $m / z 493.2785$ in the positive HR-ESI-MS, corresponding to the molecular formula $\mathrm{C}_{26} \mathrm{H}_{38} \mathrm{~N}_{4} \mathrm{O}_{4}$, suggesting an additional methylene group compared to $\mathbf{1}$. The ${ }^{1} \mathrm{H}$ and ${ }^{13} \mathrm{C}$ NMR values of $\mathbf{3}$ were almost superimposable on those of $\mathbf{1}$ (Table 1) excepting those of the $\mathrm{N}$-methyl-valine residue in 1. Instead, an $\mathrm{N}$-methyl-isoleucine residue was identified as summarized in Table 1 (Tuenter et al. 2017). ${ }^{1} \mathrm{H}-{ }^{1} \mathrm{H}$ COSY analysis confirmed the presence of an isoleucine residue. The HMBC cross-peak of H-8 of hydroxyleucine $\left(\delta_{\mathrm{H}-8} 5.01\right)$ to $\mathrm{C}-24$ of isoleucine residue $\left(\delta_{\mathrm{C}-24} 165.3\right)$ and $\mathrm{H}-25\left(\delta_{\mathrm{H}-25} 3.62\right)$ to C-24 and the $N$-methyl carbon $\left(\delta_{\mathrm{C}} 31.8\right)$ to $\mathrm{H}-25$ for this moiety confirmed that the terminal amino acid is $N$-methyl-isoleucine. Compound $\mathbf{3}$ was named cycloheisterin C (Fig. 1).

Cycloheisterin D (4) displayed an $[\mathrm{M}+\mathrm{H}]^{+}$ion peak at $\mathrm{m} / z, 485.3138$ in the positive HR-ESIMS, corresponding to the molecular formula $\mathrm{C}_{27} \mathrm{H}_{40} \mathrm{~N}_{4} \mathrm{O}_{4}$, suggesting an additional methyl group compared to 3 . Comparing the NMR data of $\mathbf{4}$ with those of $\mathbf{3}$ (Table 1) and the analysis of the 2D-NMR spectra led to the identification, as in $\mathbf{3}$, of the amino acids units $(\beta$ hydroxyleucine, proline and isoleucine residues) and the p-oxygenated $Z$-styrylamine group 
(Table 1$)$. The HMBC cross-peaks of the methyl signals at $\delta_{\mathrm{H}} 2.91(6 \mathrm{H}, \mathrm{s})$ to $\mathrm{C}-25\left(\delta_{\mathrm{C}} 72.2\right)$ of the isoleucine residue suggested that the terminal amino acid in $\mathbf{4}$ is $N, N$-dimethyl-isoleucine. Compound 4 was named cycloheisterin D (Fig. 1).

Cycloheisterin E (5) exhibited an $[\mathrm{M}+\mathrm{Na}]^{+}$ion peak at $\mathrm{m} / z 541.2799$ in the HR-ESI-MS spectrum, consistent with the molecular formula of $\mathrm{C}_{30} \mathrm{H}_{38} \mathrm{~N}_{4} \mathrm{O}_{4}$. Comparing the NMR data of 5 with those of 1-4 (Table 1) and detailed analysis of the 2D-NMR spectra showed that it had the same macrocycle (inside) composed of the amino acids units ( $\beta$-hydroxyleucine and proline) and the p-oxygenated $Z$-styrylamine group (Table 1 ). The ${ }^{1} \mathrm{H}$ and ${ }^{13} \mathrm{C}$-NMR spectra of $\mathbf{5}$ exhibited signals corresponding to an aromatic amino acid $\left[\delta_{\mathrm{H}} 7.20-7.30,5 \mathrm{H}\right]$. Extensive 2DNMR analysis enabled the full assignments of the $N, N$-dimethyl phenylalanine. (Tuenter et al. 2017). The presence of the $N, N$-dimethyl groups was confirmed by the HMBC correlation between the methyl signals at $\delta_{\mathrm{H}} 2.97(6 \mathrm{H}, \mathrm{s})$ and C-25 $\left(\delta_{\mathrm{C}} 68.1\right)$ of the phenylalanine residue. The HMBC correlation between H-8 ( $\left.\delta_{\mathrm{H}} 4.82\right)$ of the $\beta$-hydroxyleucine and the C-24 $\left(\delta_{\mathrm{C}} 165.0\right)$ of the $N, N$-dimethyl phenylalanine confirmed it to be the terminal amino acid moiety. Compound 5 was named cycloheisterin E (Fig. 1).

The relative stereochemistry for $\mathbf{1 - 5}$ was proposed from the ${ }^{1} \mathrm{H}$ NMR coupling constants, ${ }^{13} \mathrm{C}$ NMR data, and NOESY analysis and agrees with that of anorldianine (6) (El-Seedi et al. 2005, Dongo et al. 1989, Medina et al. 2016). From the solution NMR data, it is evident that the $\beta$ hydroxyleucine unit has a relative erythro configuration based on the ${ }^{3} J_{8,9}$ values of $8.3 \mathrm{~Hz}$ (Dias et al. 2007). In the ${ }^{13} \mathrm{C}$ NMR spectra of $\mathbf{1 - 5}$ (Table 1$)$, the chemical shifts of C-9 $\left(\delta_{\mathrm{C}} \approx 83.4\right)$ and of C-8 $\left(\delta_{\mathrm{C}} \approx 53.1\right)$ suggest an L-erythro absolute configuration for the $\beta$-hydroxyleucine moiety, as reported for cyclopeptide alkaloids (Caro et al. 2012). In addition, the NOESY spectrum of 1-5 exhibits a NOE cross-peak between H-9 and H-20, suggesting that H-9 is located in the $\beta$ position. In the NOESY spectrum, cross-peaks were observed between $\mathrm{H}-9 / \mathrm{H}-21$ and $\mathrm{H}-8 / \mathrm{H}-$ 22 whereas H-9 shows no cross-peak with H-8, indicating that they are in the antiposition. This 
evidence suggests that the $\beta$-hydroxyleucine moiety in 1-5 has a L-erythro configuration. The NOE effect observed between $\mathrm{H}-25$ and $\mathrm{H}-1^{\prime}$ indicated that these protons are co-facially oriented. The configuration of the amino acid in the side chain ( $N$-methyl-valine in $\mathbf{1}, \mathrm{N}, \mathrm{N}$ dimethyl-valine in 2, N-methyl-isoleucine in $\mathbf{3}, \mathrm{N}, \mathrm{N}$-dimethyl-isoleucine in $\mathbf{4}$, and $\mathrm{N}, \mathrm{N}$ dimethyl-phenylalanine in 5) and the proline of cycloheisterins A-E could be deduced by comparing the ${ }^{13} \mathrm{C}-\mathrm{NMR}$ chemical shift values to the previously reported data of similar compounds (El-Seedi et al. 2005, Kang et al. 2015, Maldaner et al. 2011, Suksamrarn et al. 2005). Considering that the majority of plant cyclopeptides are composed of L-amino acids (Medina et al. 2016, Tuenter et al. 2017), the L-configuration can be assumed for the amino acids present in the cycloheisterins A-E, reported here, although this could not be confirmed by experimental evidence for all chiral centers.

In summary, six compounds were isolated from the crude alkaloid extract of $H$. parvifolia leaves, among them five previously undescribed cyclopeptide alkaloids from the 4(14) type, 4 amino acid constituents outside and the 14-atoms of the macrocycle (inside). Their structures were established by different spectroscopic methods including 1D- and 2D-NMR experiments as well as HR-ESI-MS analysis. Compound $\mathbf{6}$ (anorldianine) that has a unique substructure containing proline, was previously isolated from Heisteria nitida (El-Seedi et al. 1999). Compounds 1-5 were derivatives of anorldianine and differed in only the terminal amino acid which was $\mathrm{N}$-methyl-valine in $\mathbf{1}, \mathrm{N}, \mathrm{N}$-dimethyl-valine in $\mathbf{2}, \mathrm{N}$-methyl-isoleucine in $\mathbf{3}, \mathrm{N}, \mathrm{N}$ dimethyl-isoleucine in 4, and $N, N$-dimethyl-phenylalanine in 5. Cyclopeptide alkaloids have only been reported from a few families of the plant kingdom, in fact, they seem to be quite rare and present in small quantities. This kind of cyclopeptide alkaloids was isolated only in Canthium anorldianum (Rubiaceae) and Heisteria nitida (Olacaceae). Further phytochemical investigation on Heisteria species are needed to verify wether anorldianine derivative 
cyclopeptide alkaloids could be considered as a taxonomic markers for the genus Heisteria. The cytotoxic activity of compounds 1-6 against the chronic myeloid leukemia (K562) cell line was evaluated. Only compounds 2, 4 and $\mathbf{6}$ exhibited an antiproliferative activity at the concentration $100 \mu \mathrm{M}$ with cell growth inhibition of $46 \%, 44 \%$, and $43 \%$, respectively, whereas compounds 1, 3, and $\mathbf{5}$ showed cell growth inhibition of 13\%, 19\%, and 36\%, respectively at the same concentration.

\section{Experimental}

\subsection{General experimental procedures}

Optical rotations were measured on a Perkin Elmer model 341 polarimeter $\left(589 \mathrm{~nm}, 20^{\circ} \mathrm{C}\right)$. IR spectra were obtained on a Nicolet Avatar 320 FT-IR spectrometer with KBr disks. NMR spectra were acquired in $\mathrm{CD}_{3} \mathrm{OD}$ on Bruker Avance DRX III 500 instruments $\left({ }^{1} \mathrm{H}\right.$ at $500 \mathrm{MHz}$ and ${ }^{13} \mathrm{C}$ at $\left.125 \mathrm{MHz}\right)$. Standard pulse sequences and parameters were used to obtain 1D- $\left({ }^{1} \mathrm{H}\right.$ and $\left.{ }^{13} \mathrm{C}\right)$ and 2D- (COSY, ROESY, HSQC and HMBC) NMR spectra. HR-ESI-MS experiments were performed using a Micromass Q-TOF high-resolution mass spectrometer (Manchester, UK). Mass spectra were recorded in the positive-ion mode in the range $\mathrm{m} / \mathrm{z}, 100-2000$, with a mass resolution of 20000 and an acceleration voltage of $0.7 \mathrm{kV}$. Flash chromatography was conducted on a Grace Reveleris system equipped with dual UV and ELSD detection using

Grace ${ }^{\circledR}$ cartridges (Silica gel or RP-18). A prepacked RP-C 18 column (Phenomenex 250 x 15 $\mathrm{mm}$, Luna $5 \mu$ ) was used for semi-preparative HPLC. The eluting mobile phase consisted of $\mathrm{H}_{2} \mathrm{O}$ with TFA $(0.0025 \%)$ and $\mathrm{CH}_{3} \mathrm{CN}$ with a flow rate of $5 \mathrm{~mL} / \mathrm{min}$ and the chromatogram was monitored at 210, 250, 270, and $300 \mathrm{~nm}$.TLC was performed on precoated silica gel $60 \mathrm{~F}_{254}$ Merck and compounds were visualized by spraying the dried plates with Dragendorff's reagent.

\subsection{Plant material}


The leaves of Heisteria parvifolia Sm. were collected in Agboville forest in August 2016. They are identified by Pr. Akke Assi in the national center florestic of Félix Houphouët-Boigny University of Côte d'Ivoire (Ake assi 11049).

\subsection{Extraction and isolation}

The dried powdered leaves of $H$. parvifolia $(1 \mathrm{~kg})$ were wetted with $50 \%$ aq. $\mathrm{NH}_{4} \mathrm{OH}(500 \mathrm{~mL})$, macerated overnight and then percolated with $15 \mathrm{~L}$ of EtOAc. The organic solvent was concentrated under reduced pressure. The crude extract (26 g) was suspended in $2 \mathrm{~L}$ of EtOAc and extracted with an aqueous $2 \% \mathrm{H}_{2} \mathrm{SO}_{4}$ solution $(3 \times 2 \mathrm{~L})$. The acid phase was made alkaline with aqueous $\mathrm{NH}_{3}$ and extracted with $3 \times 2 \mathrm{~L}$ of $\mathrm{CHCl}_{3}$. The $\mathrm{CHCl}_{3}$ solution was washed with $\mathrm{H}_{2} \mathrm{O}(2 \mathrm{~L})$, dried $\left(\mathrm{Na}_{2} \mathrm{SO}_{4}\right)$ and evaporated in vacuo to give $500 \mathrm{mg}$ of crude alkaloid extract (yield $0.05 \%$ ). The crude alkaloid extract was subjected to silica gel flash chromatography eluted with increasingly polar $\mathrm{CHCl}_{3} / \mathrm{MeOH}$ (100:00-95:05) for $25 \mathrm{~min}$, to yield 26 fractions (F1-26). Fractions F6, F8, F10, F12, F14 and F17 were subjected separately to semipreparative HPLC RP-18 chromatography, by eluting with an isocratic gradient $\left(28 \% \mathrm{CH}_{3} \mathrm{CN}\right)$. Compound $4\left(t_{R} 13.2 \mathrm{~min}, 31 \mathrm{mg}\right.$ ) was obtained from fractions $\mathrm{F} 6$ and F8, compound 5 ( $t_{R} 14.9 \mathrm{~min}, 4 \mathrm{mg}$ ) from fraction F10, compound $6\left(t_{R} 10.6 \mathrm{~min}, 6 \mathrm{mg}\right.$ ) from fraction F12, compounds $2\left(t_{R} 14.6\right.$ $\min , 6 \mathrm{mg}$ ) and $\mathbf{3}\left(t_{R} 17.3 \mathrm{~min}, 4 \mathrm{mg}\right)$ from fraction $\mathrm{F} 14$, and compound $\mathbf{1}\left(t_{R} 11.3 \mathrm{~min}, 5 \mathrm{mg}\right)$ from fraction F17.

\subsubsection{Cycloheisterin A (1)}

White amorphous powder; $[\alpha]^{20}{ }_{\mathrm{D}}=-148\left(c\right.$ 0.5; MeOH); UV (MeOH) $\lambda_{\max }$ (abs.) 222 (1.66), 274 (0.33); IR $v_{\max } 3395,2972,1682,1508,1205,1133,984,720 ;{ }^{1} \mathrm{H}$ and ${ }^{13} \mathrm{C}$ NMR, see Table 1; HR-ESI-MS (positive ion mode) $m / z$ 457.2807 [M + H] ${ }^{+}\left(\right.$calcd for $\mathrm{C}_{25} \mathrm{H}_{37} \mathrm{~N}_{4} \mathrm{O}_{4}, 457.2815$ ).

\subsubsection{Cycloheisterin B (2)}


White amorphous powder; $[\alpha]^{20} \mathrm{D}=-187(c$ 0.52; $\mathrm{MeOH}) ; \mathrm{UV}(\mathrm{MeOH}) \lambda_{\max }($ abs.) $222(0.10)$, 282 (0.01); IR $v_{\max } 3439,2969,1681,1508,1204,1136,700 ;{ }^{1} \mathrm{H}$ and ${ }^{13} \mathrm{C}$ NMR, see Table 1; HR-ESI-MS (positive ion mode) $m / z 471.2979[\mathrm{M}+\mathrm{H}]^{+}$(calcd for $\mathrm{C}_{26} \mathrm{H}_{39} \mathrm{~N}_{4} \mathrm{O}_{4}, 471.2971$ ).

\subsubsection{Cycloheisterin C (3)}

White amorphous powder; $[\alpha]^{20} \mathrm{D}=-135(c 0.31 ; \mathrm{MeOH}) ; \mathrm{UV}(\mathrm{MeOH}) \lambda_{\max }$ (abs.) 224 (1.38), 276 (0.37); IR $v_{\max } 3388,2965,1686,1506,1206,1133,985,719 ;{ }^{1} \mathrm{H}$ and ${ }^{13} \mathrm{C}$ NMR, see Table 1; HR-ESI-MS (positive ion mode) $m / z 493.2785[\mathrm{M}+\mathrm{Na}]^{+}$(calcd for $\mathrm{C}_{26} \mathrm{H}_{38} \mathrm{~N}_{4} \mathrm{O}_{4} \mathrm{Na}$, 493.2791).

\subsubsection{Cycloheisterin D (4)}

White amorphous powder; $[\alpha]^{20} \mathrm{D}=-179\left(c 0.23\right.$; MeOH); UV (MeOH) $\lambda_{\max }$ (abs.) $222(3.21)$, 280 (0.3); IR $v_{\max } 3395,2972,1682,1508,1205,1133,720 ;{ }^{1} \mathrm{H}$ and ${ }^{13} \mathrm{C}$ NMR, see Table 1; HRESI-MS (positive ion mode) $m / z, 485.3138[\mathrm{M}+\mathrm{H}]^{+}\left(\right.$calcd for $\mathrm{C}_{27} \mathrm{H}_{41} \mathrm{~N}_{4} \mathrm{O}_{4}, 485.3128$ ).

\subsubsection{Cycloheisterin E (5)}

White amorphous powder; $[\alpha]^{20} \mathrm{D}=-91(c 0.41 ; \mathrm{MeOH})$; UV (MeOH) $\lambda_{\max }($ abs.) $222(0.91)$, 274 (0.5); IR $v_{\max } 3439,2969,1681,1508,1204,1136,700 ;{ }^{1} \mathrm{H}$ and ${ }^{13} \mathrm{C}$ NMR, see Table 1; HRESI-MS (positive ion mode) $m / z 541.2799[\mathrm{M}+\mathrm{Na}]^{+}\left(\right.$calcd for $\mathrm{C}_{30} \mathrm{H}_{38} \mathrm{~N}_{4} \mathrm{O}_{4} \mathrm{Na}, 541.2791$ ).

\section{Cytotoxicity bioassay by MTS}

K562 cells (chronic myeloid leukemia) were trypsinized, harvested, and spread onto 96-well flat-bottom plates at a density of 1000 cells per well, and then incubated for $24 \mathrm{~h}$ in RPMI 1640 Medium supplemented with $10 \%$ fetal bovine serum and antibiotics. After culture, the cells were treated with compounds 1-6 for $72 \mathrm{~h}$. The cell cultures were then analyzed using 3-(4,5dimethylthiazol-2-yl)-5-(3-carboxymethoxyphenyl)-2-(4-sulfophenyl)-2H-tetrazolium inner salt (MTS) according to the manufacturer's instructions (Promega Corporation, Charbonnières, France). Camptothecin was used as positive control. MTS is bioreduced by cells into a colored 
formazan product. Absorbance was analyzed at a wavelength of $540 \mathrm{~nm}$ with a Multiskan Ex microplate absorbance reader (Thermo Scientific, Paris, France). Percentage of cell growth was calculated as $100 \% \times$ (absorbance of the treated cells) / (absorbance of the negative control cells). Control cells were treated with complete culture medium containing $0.2 \%$ DMSO. The values represent averages of three independent experiments.

\section{Supporting Information}

HR-ESI-MS and 1D- and 2D-NMR spectra of compounds 1-5.

\section{Acknowledgements}

The authors are grateful to Conseil Regional Champagne Ardenne, Conseil General de la Marne, Ministry of Higher Education, Research and Innovation (France) (MESRI) and EUprogramme FEDER to the PlAneT CPER project for financial support as well as the Ministry of Research of Côte d'Ivoire.

\section{References bibliographiques}

Abbiw, D., 1990. Useful Plants of Ghana: West African Uses of Wild and Cultivated Plants. London: Intermediate Technology Publications, Royal Botanic Gardens, Kew.

Burkill H.M., 1997. The useful plants of West Tropical Africa. Edition 2, Vol. 4, families MR, 284-285. Kew Royal Botanic Gardens.

Cairo-Valera, G., De Budowski, J., Delle-Monache, F., Marini-Bettolo, G.B., 1977. A new psychoactive drug : Heisteria olivae (Olacaceae). Atti Accad. Naz. Lincei, Cl. Sci. Fis. Mat. Nat. Rend. 62, 363-364.

Caro, M.S., de Oliveira, L.H., Ilha, V., Burrow, R.A., Dalcol, I.I., Morel, A.F., 2012. Absolute configuration of franganine. J. Nat. Prod.75, 1220-1222.

Dias, G.C., Gressler, V., Hoenzel, S.C., Silva, U.F., Dalcol, I.I., Morel, A.F., 2007. Constituents of the roots of Melochia chamaedrys. Phytochemistry 68, 668-672. 
Dirsch, V., Wiemann, W., Wagner, H., 1992. Anti-inflammatory activity of triterpene quinonemethides and proanthocyanidins from the stem bark of Heisteria pallida Engl. Pharm. Pharmacol. Lett., 2, 184-186.

Dirsch, V., Neszmèlyi, A., Wagner, H., 1993. A trimeric propelargonidin from stem bark of Heisteria pallida. Phytochemistry 34, 291-293.

Dongo, E., Ayafor, J.F., Sondengam, B.L.; Connolly, J.D., 1989. A new peptide alkaloid from Canthium anorldianum. J. Nat. Prod.52, 840-843.

El-Seedi, H.R., Gohil, S., Perera, P., Torssell, K.B.G., Bohlin, L., 1999. Cyclopeptide alkaloids from Heisteria nitida. Phytochemistry 52, 1739-1744.

El-Seedi, H.R., Larson, S., Backlund, A., 2005. Chemosystematic value of cyclopeptide alkaloids from Heisteria nitida (Olacaceae). Biochem. Syst. Ecol. 33, 831-839.

El-Seedi, H.R., Zahra, M.H., Göransson, U., Verpoorte, R., 2007. Cyclopeptide alkaloids. Phytochem. Rev. 6, 143-165.

Gournelis, D.C., Laskaris, G.G., Verpoorte, R., 1997. Cyclopeptides alkaloids. Nat. Prod. Rep. $14,75-82$.

Joullie, M.M., Richard, D.J., 2004. Cyclopeptide alkaloids: chemistry and biology. Chem. Comm. 18, 2011-2015.

Kang, K.B., Ming, G., Kim, G.J., Ha, T.K., Choi, H, Oh, W.K., Sung, S.H., 2015. Jubanines FJ, cyclopeptide alkaloids from the roots of Ziziphus jujuba. Phytochemistry119,90-95.

Kraus, C.M., Neszmélyi, A., Holly, S., Wiedemann, B., Nenninger, A., Torssell, K.B., Bohlin, L., Wagner, H., 1998. New acetylenes isolated from the bark of Heisteria acuminata. J. Nat. Prod. 61, 422-427.

Kvist, L.P., Holm-Nielsen, L.B., 1987. Ethnobotanical aspects of lowland Ecuador. Opera Botanica, 92, 83-107. 
Louppe, D., Oteng-Amoako, A.A., Brink, M., in Timbers, Plant Resources of Tropical Africa (Series), 7(1), pp: 385-386. Ed. Wageningen: PROTA Foundation: Backhuys, 2008.

Malaisse, F., N'Gasse, G., Lognay, G., 2004. Heisteria parvifolia (Olacaceae), an Underestimated shrub or small tree with Oil producing seeds. Syst. Geogr. Plants. 74, 7-25. Maldaner, G., Marangon, P., Ilha, V., Caro, M.S.P., Burrow, R.A., Dalcol, I.I., Morel, A.F., 2011. Cyclopeptide alkaloids from Scutia buxifolia Reiss. Phytochemistry 72, 804-809.

Medina, R.P., Schuquel, I.T.A., Pomini, A.M., Silva, C.C., Oliveira, C.M.A., Kato, L., Nakamura, C.V., Santin, S.M.O., 2016. Ixorine, a New Cyclopeptide Alkaloid from the Branches of Ixora brevifolia. J. Braz. Chem. Soc. 27, 753-758.

Morel, A.F., Maldaner, G., Ilha, V., Missau, F., Silva, U.F., Dalcol, I.I, 2005. Cyclopeptide alkaloids from Scutia buxifolia Reiss and their antimicrobial activity. Phytochemistry 66, $2571-2576$

Morel, A.F., Maldaner, G., Ilha, V., 2009. Cyclopeptide Alkaloids from higher plants. Alkaloids. Chem. Biol. 67, 79-141.

Russo, E.B., 1992. Headache treatments by native peoples of the Ecuadorian Amazon: a preliminary cross-disciplinary assessment. J. Ethnopharmacol. 36, 193-206.

Schwing, K., Reyheller, C., Schaly, A., Kubik, S., Gerhards, M., 2011. Structural analysis of an isolated cyclic tetrapeptide and its monohydrate by combined IR/UV spectroscopy. Chemphyschem. 121981-1988.

Sugawara, F., Ishimoto, M., Le Van, N., Koshino, H., Uzawa, J., Yoshida, S., Kitamura, K., 1996. Insecticidal peptide from mung bean: a resistant factor against infestation with azuki bean weevil. J. Agric. Food Chem. 44, 3360-3364.

Suh, D.Y., Kim, Y.C., Kang, Y.H., Han, B.H., 1997. Metabolic cleavage of frangufoline in rodents: In Vitro and in Vivo Study. J. Nat. Prod. 60, 265-269. 
Suksamrarn, S., Suwannapoch, N., Aunchai, N, Kuno, M., Ratananukul, P., Haritakun, R., Jansakul, C., Ruchirawat, S., 2005. Ziziphine N, O, P and Q, new antiplasmodial cyclopeptide alkaloids from Ziziphus oenoplia var. brunoniana. Tetrahedron 61, 1175-1180.

Tan, N.-H., Zhou, J., 2006. Plant cyclopeptides. Chem. Rev.106, 840-895.

Tuenter, E., Foubert, K., Staerk, D., Apers, S., Pieters, L., 2017. Isolation and structure elucidation of cyclopeptide alkaloids from Ziziphus nummularia and Ziziphus spina-christi by HPLC-DAD-MS and HPLC-PDA-(HRMS)-SPE-NMR. Phytochemistry 138, 163-169. 


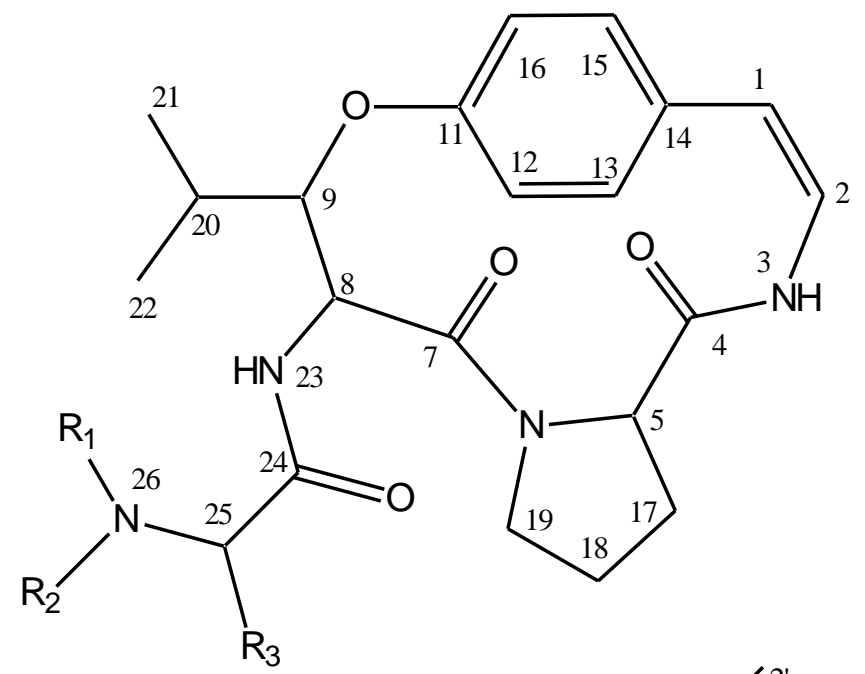

1: $\mathrm{R}_{1}=\mathrm{H}, \mathrm{R}_{2}=\mathrm{CH}_{3}, \mathrm{R}_{3}=\mathrm{A}$

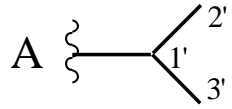

2: $\mathrm{R}_{1}=\mathrm{R}_{2}=\mathrm{CH}_{3}, \mathrm{R}_{3}=\mathrm{A}$

3: $\mathrm{R}_{1}=\mathrm{H}, \mathrm{R}_{2}=\mathrm{CH}_{3}, \mathrm{R}_{3}=\mathrm{B}$

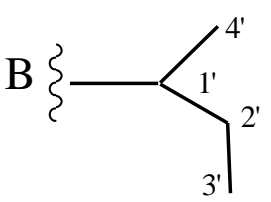

4: $\mathrm{R}_{1}=\mathrm{R}_{2}=\mathrm{CH}_{3}, \mathrm{R}_{3}=\mathrm{B}$

5: $\mathrm{R}_{1}=\mathrm{R}_{2}=\mathrm{CH}_{3}, \mathrm{R}_{3}=\mathrm{C}$

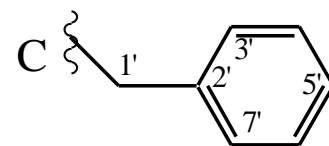

6: $\mathrm{R}_{1}=\mathrm{R}_{2}=\mathrm{CH}_{3}, \mathrm{R}_{3}=\mathrm{D}$

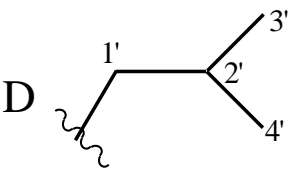

Fig. 1. Chemical structures of compounds 1-6. 


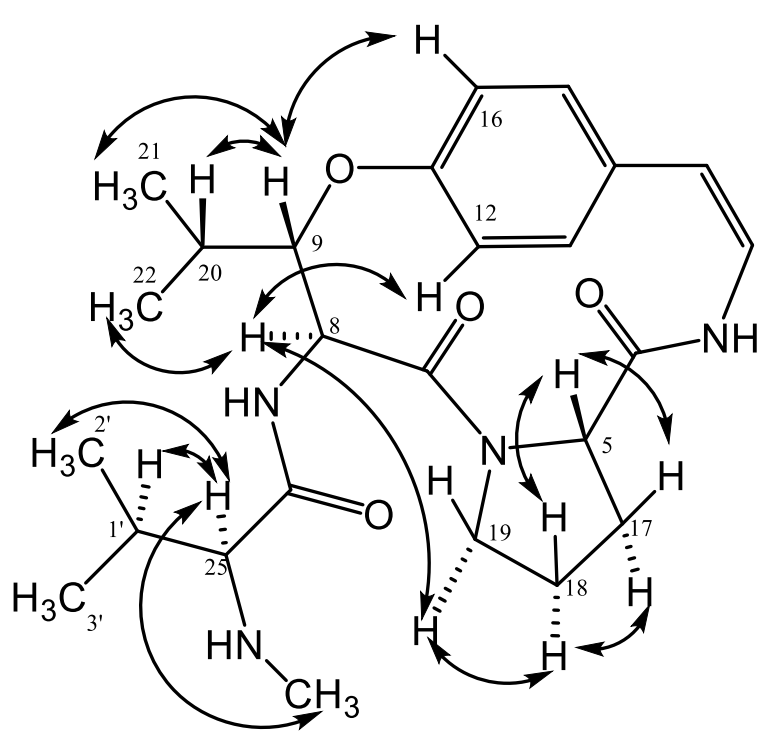

$\curvearrowleft$ NOESY

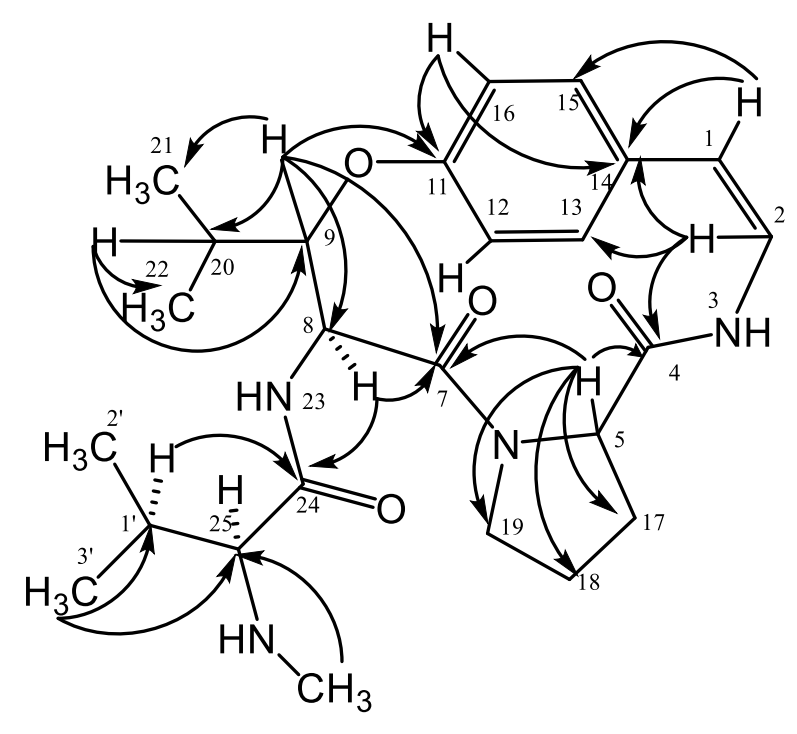

ح $\mathrm{HMBC}$

Fig. 2. Selected key HMBC and NOESY interactions for compound $\mathbf{1 .}$ 
Table 1. ${ }^{13} \mathrm{C}$ NMR spectroscopic data for compounds 1-5 (500 MHz, $\left.\mathrm{CD}_{3} \mathrm{OD}\right)$.

\begin{tabular}{|c|c|c|c|c|c|c|c|c|c|c|}
\hline & 1 & & 2 & & 3 & & 4 & & 5 & \\
\hline & $\delta_{H} \mathrm{~m}(\mathrm{~J}$ in $\mathrm{Hz})$ & $\delta_{\mathrm{C}}$ & $\delta_{\mathrm{H}} \mathrm{m}(\mathrm{J}$ in $\mathrm{Hz})$ & $\delta_{\mathrm{C}}$ & $\delta_{\mathrm{H}} \mathrm{m}(\mathrm{J}$ in $\mathrm{Hz})$ & $\delta_{\mathrm{C}}$ & $\delta_{\mathrm{H}} \mathrm{m}(\mathrm{J}$ in $\mathrm{Hz})$ & $\delta_{\mathrm{C}}$ & $\delta_{H} \mathrm{~m}(\mathrm{~J}$ in $\mathrm{Hz})$ & $\delta_{\mathrm{C}}$ \\
\hline 1 & $6.53, d(7.7)$ & 116.7 & $6.53, \mathrm{~d}(7.7)$ & 116.8 & $6.53, d(7.7)$ & 116.3 & $6.53, d(7.7)$ & 116.8 & $6.50, d(7.7)$ & 116.8 \\
\hline 2 & $6.65, \mathrm{~d}(7.7)$ & 124.9 & $6.65, \mathrm{~d}(7.7)$ & 125.0 & $6.66, \mathrm{~d}(7.7)$ & 124.9 & $6.65, \mathrm{~d}(7.7)$ & 124.9 & $6.60, \mathrm{~d}(7.7)$ & 125.0 \\
\hline 4 & - & 167.5 & - & 167.5 & - & 167.5 & - & 167.4 & - & 167.9 \\
\hline 5 & $4.16, \mathrm{dd}(7.5,1.9)$ & 62.5 & $4.14, \mathrm{~d}(7.5)$ & 62.6 & $4.15, d(7.8)$ & 62.5 & $4.12, d(8.1)$ & 62.6 & $3.72, d(8.0)$ & 62.4 \\
\hline 7 & - & 171.1 & - & 171.0 & - & 171.1 & - & 171.0 & - & 170.7 \\
\hline 8 & $5.01, d(8.3)$ & 53.1 & $5.01, d(8.5)$ & 52.0 & $5.01, d(8.3)$ & 53.1 & $5.01, d(8.5)$ & 53.0 & 4.82, (overlapped) & 53.0 \\
\hline 9 & $4.92, \mathrm{dd}(8.3,1.5)$ & 83.4 & $4.93, \mathrm{dd}(8.5,1.9)$ & 83.2 & $4.91, \mathrm{dd}(8.3,1.2)$ & 83.4 & $4.92, \mathrm{dd}(8.3,1.3)$ & 83.2 & 4.82, (overlapped) & 82.7 \\
\hline 11 & - & 157.2 & - & 157.2 & - & 157.2 & - & 157.2 & - & 157.1 \\
\hline 12 & $7.27, \mathrm{dd}(8.7,2.4)$ & 120.9 & $7.27, \mathrm{~d}(8.5)$ & 120.8 & $7.27, d(8.1)$ & 120.9 & $7.27, \mathrm{~d}(8.9)$ & 120.8 & $7.20, \mathrm{~m}$ & 119.6 \\
\hline 13 & $7.11, \mathrm{dd}(8.7,2.4)$ & 131.4 & $7.11, \mathrm{~m}$ & 131.4 & $7.11, \mathrm{~m}$ & 131.4 & $7.11, \mathrm{~m}$ & 131.4 & $7.11, \mathrm{dd}(8.5,1.5)$ & 131.3 \\
\hline 14 & - & 131.6 & - & 131.8 & - & 131.6 & - & 131.6 & - & 131.3 \\
\hline 15 & $7.11, \mathrm{dd}(8.7,2.4)$ & 131.0 & $7.11, \mathrm{~m}$ & 130.3 & $7.11, \mathrm{~m}$ & 130.5 & $7.11, \mathrm{~m}$ & 130.3 & $7.12, \mathrm{dd}(8.5,1.5)$ & 130.2 \\
\hline 16 & $7.27, \mathrm{dd}(8.7,2.4)$ & 120.9 & $7.27, d(8.5)$ & 120.8 & $7.27, d(8.1)$ & 120.9 & $7.27, d(8.9)$ & 120.8 & $7.20, \mathrm{~m}$ & 120.3 \\
\hline \multirow[t]{2}{*}{17} & $1.65, \mathrm{~m}$ & 28.2 & $1.67, \mathrm{~m}$ & 28.2 & $1.65, \mathrm{~m}$ & 28.1 & $1.64, \mathrm{~m}$ & 28.2 & $1.54, \mathrm{~m}$ & 28.6 \\
\hline & $2.21, \mathrm{dd}(11.5,4.5)$ & & $2.21, \mathrm{dd}(12.3,4.9)$ & & $2.21, \mathrm{dd}(12.1,5.8)$ & & $2.22, \mathrm{dd}(12.5,6.1)$ & & $2.01, \mathrm{dd}(11.3,4.8)$ & \\
\hline \multirow[t]{2}{*}{18} & $1.75, \mathrm{~m}$ & 23.3 & $1.75, \mathrm{~m}$ & 23.3 & $1.75, \mathrm{~m}$ & 23.3 & $1.75, \mathrm{~m}$ & 23.3 & $1.67, \mathrm{~m}$ & 23.5 \\
\hline & $1.95, \mathrm{~m}$ & & $1.97, \mathrm{~m}$ & & $1.95, \mathrm{~m}$ & & $1.97, \mathrm{~m}$ & & $1.82, \mathrm{~m}$ & \\
\hline \multirow[t]{2}{*}{19} & 3.55, brt $(9.8)$ & 46.7 & 3.55, brt $(10.8)$ & 46.7 & 3.55, brt $(9.8)$ & 46.7 & 3.58, brt $(9.3)$ & 46.8 & 3.42, brt (9.2) & 47.0 \\
\hline & $3.85, \mathrm{~m}$ & & 3.90, ddd $(10.8,7.1,3.2)$ & & $3.85, \mathrm{~m}$ & & 3.85, ddd $(10.1,9.3,7.4)$ & & $3.71, \mathrm{~m}$ & \\
\hline 20 & $2.13, \mathrm{~m}$ & 28.7 & $2.12, \mathrm{dq}(6.8,1.7)$ & 28.7 & $2.13, \mathrm{~m}$ & 28.7 & $2.11, \mathrm{~m}$ & 28.7 & $2.10, \mathrm{~m}$ & 28.6 \\
\hline 21 & $1.32, \mathrm{~d}(6.7)$ & 19.5 & $1.32, \mathrm{~d}(6.8)$ & 19.4 & $1.32, \mathrm{~d}(6.8)$ & 19.5 & $1.32, \mathrm{~d}(6.8)$ & 19.4 & $1.27, \mathrm{~d}(6.8)$ & 19.3 \\
\hline 22 & $1.05, d(6.7)$ & 13.9 & $1.07, \mathrm{~d}(6.8)$ & 14.0 & $1.06, d(6.8)$ & 13.9 & $1.07, \mathrm{~d}(6.8)$ & 14.0 & $1.02, \mathrm{~d}(6.8)$ & 14.0 \\
\hline 24 & - & 165.2 & - & 164.3 & - & 165.3 & - & 164.4 & - & 165.0 \\
\hline 25 & $3.57, \mathrm{~d}(5.4)$ & 66.7 & $3.59, d(5.3)$ & 72.7 & $3.62, d(5.0)$ & 66.2 & $3.62, \mathrm{~d}(4.8)$ & 72.2 & $4.10, \mathrm{dd}(10.4,4.5)$ & 68.1 \\
\hline \multirow[t]{2}{*}{$\boldsymbol{R}_{1}$} & $\mathrm{~N}-\mathrm{CH}_{3}$ & & $\mathrm{~N}-\mathrm{CH}_{3}$ & & $\mathrm{~N}-\mathrm{CH}_{3}$ & & $\mathrm{~N}-\mathrm{CH}_{3}$ & & $\mathrm{~N}-\mathrm{CH}_{3}$ & \\
\hline & $2.68, \mathrm{~s}$ & 31.8 & $2.92, \mathrm{~s}$ & 40.3 & $2.66, s$ & 31.8 & $2.91, \mathrm{~s}$ & 39.7 & $2.97, \mathrm{~s}$ & 41.1 \\
\hline \multirow[t]{2}{*}{$\boldsymbol{R}_{2}$} & & & $\mathrm{~N}-\mathrm{CH}_{3}$ & & & & $\mathrm{~N}-\mathrm{CH}_{3}$ & & $\mathrm{~N}-\mathrm{CH}_{3}$ & \\
\hline & & & $2.92, \mathrm{~s}$ & 41.9 & & & $2.91, \mathrm{~s}$ & 42.2 & $2.97, \mathrm{~s}$ & 41.1 \\
\hline $\boldsymbol{R}_{3}$ & Val & & Val & & iLeu & & iLeu & & Phe & \\
\hline \multirow[t]{2}{*}{$1^{\prime}$} & $2.13, \mathrm{~m}$ & 30.2 & $2.45, \mathrm{~m}$ & 27.2 & $1.88, \mathrm{~m}$ & 36.8 & $2.16, \mathrm{~m}$ & 33.9 & $3.12, \mathrm{dd}(13.8,10.6)$ & 34.3 \\
\hline & & & & & & & & & $3.40, \mathrm{~m}$ & \\
\hline \multirow[t]{2}{*}{$2^{\prime}$} & $0.95, d(6.7)$ & 16.7 & $0.93, d(6.7)$ & 15.1 & $1.02, \mathrm{~m}$ & 25.1 & $0.77, \mathrm{~m}$ & 26.3 & & 134.1 \\
\hline & & & & & $1.47, \mathrm{~m}$ & & $1.42, \mathrm{~m}$ & & & \\
\hline 3' & $0.96, d(6.7)$ & 17.5 & $0.97, d(6.7)$ & 18.7 & $0.92, \mathrm{t}(6.8)$ & 10.3 & $0.93, t(6.9)$ & 10.4 & $7.20, \mathrm{~m}$ & 129.0 \\
\hline 4' & & & & & $0.96, d(6.8)$ & 13.1 & $0.98, d(6.9)$ & 11.5 & $7.30, \mathrm{~m}$ & 128.5 \\
\hline $5^{\prime}$ & & & & & & & & & $7.21, \mathrm{~m}$ & 127.5 \\
\hline $6^{\prime}$ & & & & & & & & & $7.30, m$ & 128.5 \\
\hline $7^{\prime}$ & & & & & & & & & $7.20, \mathrm{~m}$ & 129.0 \\
\hline
\end{tabular}

